\title{
Post-cardiac arrest mortality is declining in the UK
}

\author{
Saket Girotra(D)
}

See related research by Nolan et al. http://ccforum.biomedcentral.com/articles/10.1186/s13054-016-1390-6

Cardiac arrest is a leading cause of death in the developed world. In the US, more than 500,000 patients die from a cardiac arrest every year [1]. The public health impact of cardiac arrest in the UK is also quite substantial [2]. While mortality is high, even those who survive a cardiac arrest are at a significant risk of permanent neurological damage. Thus, improving survival and reducing neurological disability is a fundamental goal of patient care and a priority for public health.

Conceptually, mortality in cardiac arrest occurs in two distinct phases. Patients either die acutely due to a failure to attain return of spontaneous circulation (ROSC), which depends on timely, high-quality resuscitation, or, alternatively, they die following ROSC due to a cascade of clinical events, which may depend on invasive treatments, quality of nursing, and critical care (post-resuscitation phase). In recent years, the postresuscitation phase has been recognized as an important phase of resuscitation. The European Resuscitation Council and the American Heart Association have published guidelines emphasizing treatment strategies for optimizing post-resuscitation care, which includes early coronary angiography, targeted temperature management (TTM), close monitoring and treatment in intensive care unit (ICU), delaying neurological prognostication, and regionalizing care [3, 4]. In its recent report Strategies to Improve Cardiac Arrest Survival the Institute of Medicine included improving systems of resuscitation care within hospitals as a key recommendation to improve outcomes [5].

In the current issue of Critical Care, Professor Nolan and colleagues provide interesting new data regarding temporal patterns of post-resuscitation management and outcomes in the UK. Using data from a national ICU audit, 63,417 patients across 286 ICUs who had received

Correspondence: saket-girotra@uiowa.edu

Division of Cardiovascular Diseases, Department of Internal Medicine,

University of lowa Carver College of Medicine, 200 Hawkins Drive, Suite 4427 RCP, lowa City, IA 52242, USA

(c) 2016 The Author(s). Open Access This article is distributed under the terms of the Creative Commons Attribution 4.0 International License (http://creativecommons.org/licenses/by/4.0/), which permits unrestricted use, distribution, and reproduction in any medium, provided you give appropriate credit to the original author(s) and the source, provide a link to the Creative Commons license, and indicate if changes were made. The Creative Commons Public Domain Dedication waiver (http://creativecommons.org/publicdomain/zero/1.0/) applies to the data made available in this article, unless otherwise stated. cardiopulmonary resuscitation and mechanical ventilation within $24 \mathrm{~h}$ were included. A substantial reduction in in-hospital mortality over an 11-year period was noted-both in patients with out-of-hospital cardiac arrest (OHCA: $70.1 \%$ in 2004 to $66.4 \%$ in 2014; riskadjusted odds ratio $[\mathrm{OR}]$ per year $0.96 ; 95 \%$ confidence interval [95\% CI] 0.95-0.97, $P$ value for trend $<0.001$ ) and in-hospital cardiac arrest (IHCA: $70.4 \%$ in 2004 to $60.3 \%$ in 2014; risk-adjusted OR per year 0.96, 95 \% CI $0.95-$ $0.97, P$ value for trend $<0.001$ ). Risk adjustment in the study was performed using a validated hierarchical model that accounted for case mix and within-ICU clustering. A decline in post-cardiac arrest mortality was accompanied by an increase in use of therapeutic hypothermia, indirectly measured as the lowest temperature of $<34{ }^{\circ} \mathrm{C}$ and avoidance of early treatment withdrawal. The rate of organ donation among non-survivors also increased threefold ( $3.1 \%$ in 2004 to $10.1 \%$ in 2014), providing a needed impetus to the low rates of organ donation in the UK [6].

The study has a few limitations, many of which were acknowledged by the authors. First, although large and comprehensive, data collection was not based on the Utstein template and important variables, such as initial rhythm, were not available. Given that cardiac arrests due to ventricular rhythms, which are associated with significantly better survival, have declined in recent years $[7,8]$, it is possible that the survival trends noted in the current study are even more pronounced. Second, data on neurological function in survivors were also not available, which makes it difficult to assess whether the substantial improvement in survival was clinically meaningful. Third, patients who experienced IHCA while already admitted and receiving care in an ICU were not included, a group that comprises over $50 \%$ of IHCA cases in the US [8].

Despite the above limitations, Nolan and colleagues need to be congratulated for providing detailed information regarding post-cardiac arrest outcomes in a large cohort of patients in the UK. Their findings add to a 
growing body of literature that has shown an unmistakable improvement in survival and neurological outcomes for both OHCA and IHCA $[8,9]$. Such data challenge the existing nihilism associated with resuscitation and can potentially invigorate research and quality improvement efforts to ensure that improved outcomes are sustained over time.

So, what is the mechanism of mortality reduction noted in this study? The authors attributed it to increasing use of hypothermia and delaying treatment withdrawal, strategies emphasized in the guidelines [3, 4]. However, causal interpretation is difficult due to the design of this study. Although recommended in all comatose survivors of cardiac arrest, the benefit of hypothermia has only been demonstrated in patients with OHCA due to ventricular rhythms $[10,11]$. Among patients with asystole or pulseless electrical activity, or patients with IHCA, the benefit of hypothermia is not proven [12]. Moreover, even among patients with OHCA, recent data from the TTM trial have shown that cooling to $36^{\circ} \mathrm{C}$ provided the same benefit as more intensive cooling to $33^{\circ} \mathrm{C}$ [13].

Accurate timing of neurological prognostication also remains a challenge in clinical practice. Current guidelines recommend delaying neurological prognostication for $72 \mathrm{~h}$ or longer after achieving normothermia to avoid premature treatment withdrawal. Over the study period, there was a notable increase in the median time between cardiac arrest and time of treatment withdrawal from 2.5 to 3.3 days. While data were not stratified by hypothermia treatment, it is conceivable that early withdrawal of care before the recommended time period does occur in some patients. However, this reflects the reality of clinical practice where physicians must balance the risk of providing care that is perceived as unnecessary or futile with the risk of premature withdrawal while managing expectations of family members and respecting patients' stated wishes.

Although the above trends in hypothermia and timing of care withdrawal are noteworthy, it isn't clear whether they are the sole drivers of survival improvement. Postresuscitation survival depends on a multitude of factors, such as timely provision of life-saving treatments, multidisciplinary teams, comprehensive critical/nursing care, and continuous quality improvement, all of which are enabled by institutional expertise, resources, and leadership. An important next step may be to examine site-level variation in survival to identify sites that consistently achieve exceptional post-cardiac arrest outcomes [14]. Identifying and evaluating processes employed by such outlier sites, using a combination of quantitative and qualitative methods could help identify best practices for post-resuscitation care [15]. Implementation of best practices across sites could ensure that the survival trends noted in this study are sustained over time.

\section{Abbreviations}

Cl: Confidence interval; ICU: Intensive care unit; IHCA: In-hospital cardiac arrest; OHCA: Out-of-hospital cardiac arrest; OR: Odds ratio; TTM: Targeted temperature monitoring

\section{Funding}

Dr. Saket Girotra is supported by career development award K08HL122527 from the National Heart Lung and Blood Institute.

Authors' contributions

Dr. Saket Girotra is fully responsible for the content of this editorial.

\section{Authors' information}

Dr. Saket Girotra is an Assistant Professor of Medicine in the Division of Cardiovascular Diseases, Department of Medicine at University of lowa Carver College of Medicine

\section{Competing interests}

The author of this editorial has an interest in resuscitation science, specifically post-resuscitation care.

\section{Consent for publication}

All authors have reviewed the manuscript and provided consent for publication.

Published online: 29 September 2016

\section{References}

1. Mozaffarian D, Benjamin EJ, Go AS, Arnett DK, Blaha MJ, Cushman M, Das SR, de Ferranti S, Despres JP, Fullerton HJ, Howard VJ, Huffman MD, Isasi CR, Jimenez MC, Judd SE, Kissela BM, Lichtman JH, Lisabeth LD, Liu S, Mackey RH, Magid DJ, McGuire DK, Mohler 3rd ER, Moy CS, Muntner P, Mussolino ME, Nasir K, Neumar RW, Nichol G, Palaniappan L, Pandey DK, Reeves MJ, Rodriguez CJ, Rosamond W, Sorlie PD, Stein J, Towfighi A, Turan TN, Virani SS, Woo D, Yeh RW, Turner MB, American Heart Association Statistics C and Stroke Statistics S. Heart Disease and Stroke Statistics-2016 Update: a report from the American Heart Association. Circulation. 2016;133:e38-360.

2. Nolan JP, Neumar RW, Adrie C, Aibiki M, Berg RA, Bbttiger BW, Callaway C, Clark RS, Geocadin RG, Jauch EC, Kern KB, Laurent I, Longstreth WT, Merchant RM, Morley P, Morrison L, Nadkarni V, Peberdy MA, Rivers EP, Rodriguez-Nunez A, Sellke FW, Spaulding C, Sunde K, Vanden Hoek T. Postcardiac arrest syndrome: epidemiology, pathophysiology, treatment, and prognostication: a scientific statement from the International Liaison Committee on Resuscitation; the American Heart Association Emergency Cardiovascular Care Committee; the Council on Cardiovascular Surgery and Anesthesia; the Council on Cardiopulmonary, Perioperative, and Critical Care; the Council on Clinical Cardiology; the Council on Stroke (Part II). Int Emerg Nurs. 2010;18:8-28.

3. Callaway CW, Donnino MW, Fink EL, Geocadin RG, Golan E, Kern KB, Leary M, Meurer WJ, Peberdy MA, Thompson TM, Zimmerman JL. Part 8: PostCardiac Arrest Care: 2015 American Heart Association Guidelines Update for Cardiopulmonary Resuscitation and Emergency Cardiovascular Care. Circulation. 2015;132:S465-82.

4. Nolan JP, Soar J, Cariou A, Cronberg T, Moulaert VR, Deakin CD, Bottiger BW, Friberg H, Sunde K, Sandroni C. European Resuscitation Council and European Society of Intensive Care Medicine Guidelines for Postresuscitation Care 2015: Section 5 of the European Resuscitation Council Guidelines for Resuscitation 2015. Resuscitation. 2015:95:202-22.

5. IOM (Institute of Medicine). Strategies to improve cardiac arrest survival: a time to act. Washington, DC: The National Academies Press; 2015.

6. Department of Health. Organs for transplants: a report from the organ donation taskforce. http://webarchive.nationalarchives.gov.uk/20130107105354/http:/ www.dh.gov.uk/en/Publicationsandstatistics/Publications/ PublicationsPolicyAndGuidance/DH_08212. Accessed 22 Aug 2016.

7. Blom MT, Beesems SG, Homma PC, Zijlstra JA, Hulleman M, van Hoeijen DA Bardai A, Tijssen JG, Tan HL, Koster RW. Improved survival after out-ofhospital cardiac arrest and use of automated external defibrillators. Circulation. 2014;130:1868-75.

8. Girotra S, Nallamothu BK, Spertus JA, Li Y, Krumholz HM, Chan PS. Trends in survival after in-hospital cardiac arrest. N Engl J Med. 2012;367:1912-20. 
9. Chan PS, McNally B, Tang F, Kellermann A, Group CS. Recent trends in survival from out-of-hospital cardiac arrest in the United States. Circulation. 2014;130:1876-82.

10. Hypothermia after Cardiac Arrest Study Group. Mild therapeutic hypothermia to improve the neurologic outcome after cardiac arrest. N Engl J Med. 2002;346:549-56.

11. Bernard SA, Gray TW, Buist MD, Jones BM, Silvester W, Gutteridge G, Smith K. Treatment of comatose survivors of out-of-hospital cardiac arrest with induced hypothermia. N Engl J Med. 2002;346:557-63.

12. Girotra S, Chan PS, Bradley SM. Post-resuscitation care following out-ofhospital and in-hospital cardiac arrest. Heart. 2015;101:1943-9.

13. Nielsen N, Wetterslev J, Cronberg T, Erlinge D, Gasche Y, Hassager C, Horn J, Hovdenes J, Kjaergaard J, Kuiper M, Pellis T, Stammet P, Wanscher M, Wise MP, Aneman A, Al-Subaie N, Boesgaard S, Bro-Jeppesen J, Brunetti I, Bugge JF, Hingston CD, Juffermans NP, Koopmans M, Kober L, Langorgen J, Lilia G, Moller JE, Rundgren M, Rylander C, Smid O, Werer C, Winkel P, Friberg H, Investigators TTMT. Targeted temperature management at 33 degrees $C$ versus 36 degrees $C$ after cardiac arrest. N Engl J Med. 2013;369:2197-206.

14. Bradley EH, Curry LA, Ramanadhan S, Rowe L, Nembhard IM, Krumholz HM. Research in action: using positive deviance to improve quality of health care. Implement Sci. 2009;4:25.

15. Chan PS, Krein SL, Tang F, Iwashyna TJ, Harrod M, Kennedy M, Lehrich J, Kronick S. American Heart Association's Get With the GuidelinesResuscitation I. Resuscitation Practices Associated With Survival After InHospital Cardiac Arrest: A Nationwide Survey. JAMA Cardiol. 2016;1:189-97. 